\title{
Discurso religioso e produção de subjetividades em uma prisão feminina: um controle de almas?
}

\section{Religious discourse and production of subjectivities in a female prison: a control of souls?}

\author{
Clara Luisa Oliveira Silva* \\ Luiz Alex Silva Saraiva**
}

Resumo: Objetiva-se analisar as relações entre discurso religioso e produção de subjetividades em uma prisão feminina, o que foi feito por meio de um estudo de caso qualitativo, realizado na unidade feminina de um dos centros de ressocialização da Associação de Proteção aos Condenados (APAC). Foram realizadas 26 entrevistas com recuperandas e quatro entrevistas com dirigentes, corpus interpretado por meio da análise estruturalista do discurso. Os principais resultados sugerem que as relaçôes que o sujeito estabelece com o espiritual são objeto de regulação no espaço social da APAC, o que se insere em um contexto de estratégia biopolítica na medida em que é garantida por uma razáo governamental que permite a assistência religiosa na prisão ao mesmo tempo em que se confunde com os efeitos de um poder pastoral.

Palavras-chave: Discurso religioso. Subjetividade. Relaçóes de poder.

Abstract: Our goal is to analyze the relationship between religious discourse and the production of subjectivities in a female prison, which was done through a qualitative case study, conducted at the female unit of one of the condemned protection associations (APAC) resocialization centers. Twenty-six interviews with recovery and as and four interviews with managers were performed, corpus interpreted through the structuralist discourse analysis. The main results suggest that the relations that the subject establishes with the spiritual are the object of regulation in the social space of APAC, which is inserted in a context of biopolitical strategy insofar as it is guaranteed by a political reason that allows religious assistance in the community. At the same time, it was confusing itself with the effects of pastoral power.

Keywords: Religious discourse. Subjectivity. Power relations.

\section{Introdução}

Neste artigo, objetiva-se analisar as relaçóes entre discurso religioso e produção de subjetividades em uma prisão feminina. Subjacente a esse objetivo, está a problemática da produção (e controle) da subjetividade nas organizaçóes. Em linhas gerais, constituem pressupostos que orientam este trabalho a noção de que as práticas discursivas se apresentam como aspectos importantes na compreensão das organizações (Westwood;

\footnotetext{
* Professora EBTT do IFSP. Doutoranda em Administração pela UFMG. ORCID: 0000-0002-33436439 - contato: claralosilva@hotmail.com

** Professor Associado da Faculdade de Ciências Econômicas da UFMG. Doutor em Administração (UFMG). Orcid: 0000-0001-5307-9750 - contato: saraiva@face.ufmg.br
} 
Linstead, 2001; Mumby; Clair, 1997), bem como a ideia de que estas práticas discursivas se relacionam com a produçáo de subjetividades nas organizaçóes, sendo a subjetividade compreendida a partir do enfoque histórico-cultural (González Rey, 2003; 2009).

De modo específico, o interesse aqui recai sobre as prisôes, organizaçóes que se inserem na categoria do que Goffman (1961) chamou de instituições totais, lugares constituídos por processos de mobilização de subjetividades, por processos que denotam uma espécie de ataques ao eu, de desfiguraçáo e profanação do eu. Partindo da possibilidade de ampliação do horizonte de compreensão das instituiçôes totais, no geral, e das prisóes, no caso particular, ao admiti-las como realidades sociais coformadas por discursos velados ou explícitos, que encerram matizes distintos, inconstantes ou mesmo contraditórios, discursos que nem sempre são reproduzidos de maneira consoante àquela lógica de plano racional único, questiona-se as implicaçóes da (re)produção do discurso religioso nas prisōes, um discurso que, segundo Orlandi (2003), se constitui a partir de um sentido de desigualdade.

Por meio de Rodrigues (2005), Vargas (2005), Quiroga (2005), Vilhena (2015), Livramento e Rosa (2016), e Nunes (2017) forma-se o entendimento de que a prática religiosa na prisão incorpora sentidos múltiplos. A prática religiosa, a qual se interpreta como sendo uma prática discursiva (Foucault, 2004), é discurso norteador de condutas (Vilhena, 2015), pode se fundar em uma lógica fundamentalista e opressiva (Quiroga, 2005) ou, de modo contrário, pode representar momentos de singularização dos sujeitos (Quiroga, 2005), pode reorganizar as biografias dos sujeitos na prisão (Rodrigues, 2005) e engendrar processos de ressignificação (Nunes, 2017), configurando-se como uma maneira de lidar com o encarceramento (Livramento; Rosa, 2016).

Ademais, a linha de argumentaçáo construída destaca que as interfaces entre o discurso religioso e a produção de subjetividades estão atravessadas por relações de poder. Assim, considerando aspectos da analítica foucaultiana (Foucault, 1988; 2008), afirma-se que a produção de subjetividades por meio de práticas discursivas religiosas é de um processo em que estão implicadas dinâmicas de poder que remetem a uma noçáo de poder pastoral, bem como a ideia de biopoder.

Após esta introdução, quatro partes estão organizadas no texto. Na primeira parte, apresenta-se uma discussão teórica que procura relacionar as categorias que conformam este estudo, discursos e subjetividades, e ainda elementos da analítica foucaultiana do poder para a investigação dos efeitos do discurso religioso no espaço social da prisão. A segunda parte se caracteriza pela descrição dos procedimentos metodológicos realizados. Em seguida, compóe-se uma narrativa que destaca a análise dos discursos colhidos na pesquisa de campo. Ao final, busca-se fazer algumas consideraçóes sobre o esforço reflexivo empreendido e propiciado por este estudo.

\section{Discurso religioso e subjetividades nas prisóes: sobre controles e resistências}

As organizaçôes podem ser concebidas como um conjunto de linguagens (Westwood; Linstead, 2001), algo que se constitui no e pelo discurso (Mumby; Clair, 1997). Os 
discursos são práticas que se organizam dentro de inúmeros sentidos subjetivos, em cuja totalidade encerra-se o seu valor heurístico para o entendimento da realidade social (González Rey, 2003). Manifestando concordância com esse raciocínio de González Rey (2003), defende-se ainda as inter-relaçôes entre discursos e subjetividades, ou, mais precisamente, as relaçóes entre o discurso como prática social que influencia os modos de ser e se relacionar em determinados espaços.

Mas, afinal, o que é subjetividade? É preciso dizer, de início, que não existe uma versão unívoca e homogênea a respeito da noção de subjetividade. Ao contrário, pululam versóes construídas sob diferentes bases epistemológicas, metodológicas e conceituais (Paula; Palassi, 2007). De modo a orientar as reflexóes desta pesquisa, adota-se para o estudo da subjetividade o enfoque histórico-cultural (González Rey, 2003; 2009).

Distante de tudo que remeta ao invariante universal, ao que permanece estático no tempo ou ainda fora de contexto, a subjetividade, à luz do enfoque histórico-cultural, se afigura, por conseguinte, como uma produção de sentidos histórica e contextualmente localizada. Em linhas gerais, a subjetividade traduz o encontro das histórias singulares de instâncias sociais e sujeitos individuais com os contextos sociais e culturais multidimensionais, contextos representados pelas instituiçóes, pelos tipos de ação social do homem. Nesses contextos, os processos de subjetivaçáo são operados mediante as relaçốes entre pessoas que devem sua origem a outros espaços sociais. Tais relaçóes são, em grande parte, delineadas pelos códigos sociais e emocionais, elementos que expressam as configurações de sentido já institucionalizadas capazes, assim, de produzir e reproduzir mitos, memórias, discursos e até outras formas de subjetivação social (González Rey, 2009).

Alinhados ao entendimento de González Rey (2003; 2009), mas para além dele, refletimos, por assim dizer, que a ideia de subjetividade não prescinde da compreensão das experiências e sentidos de sujeitos e sujeitas a partir de uma abordagem interseccional (Crenshaw, 2002). Em outras palavras: importa o gênero, a classe, a raça, e outros marcadores da diferença de quem produz sentidos.

Aliás, a unidade teórica essencial do conceito de subjetividade é a categoria sentido (González Rey, 2003; 2009). O sujeito produz sentido quando produz registros emocionais amarrados aos significados e as necessidades que vão sendo cultivados ao longo de sua história. A produção de sentidos, por seu turno, não fica circunscrita ao campo individual, nem ao social, pois encerra o que é constituído nos dois campos dentro de um mesmo sistema. Não é sem motivo, pois, que a subjetividade emerge como sendo esse complexo sistema cujos dois componentes, o individual e o social, se constituem de forma recíproca. Toda produção de sentido "[...] está associada a uma configuração pessoal que tem uma história e um contexto social que se configura de uma forma determinada diante da ação concreta de um sujeito, e que também tem uma história na vida desse sujeito" (González Rey, 2009, p. 144). Assim, no caso das organizaçóes prisionais, quais as relaçóes entre o discurso religioso e a produçáo de subjetividades? Quais os aspectos envolvidos na (re)produçáo do discurso religioso na prisão?

Para pensar as relaçôes entre discurso religioso e a produção de subjetividades, é preciso definir o que norteia esta prática discursiva e, para isso, Orlandi (2003) oferece algumas bases. Quando fala de discurso religioso, Orlandi (2003, p. 242) afirma que é "aquele em que fala a voz de Deus: a voz do padre - ou do pregador, ou em geral, 
de qualquer representante seu - é a voz de Deus". O discurso religioso marca e é marcado por uma desigualdade na relação, isto porque o locutor, Deus, pertence a uma instância espiritual, ao passo que seus ouvintes, a mulher e o homem, se localizam no plano temporal. A partir dessa desigualdade são produzidas outras desigualdades que contrapõem as noções de imortalidade/mortalidade ou mesmo de vida/morte. Portanto, nesta desigualdade, Deus domina sujeitas e sujeitos.

Uma reflexão sobre a (re)produção do discurso na prisão foi tecida a partir das elaboraçóes teóricas de Orlandi (2003), Vilhena (2015), Livramento e Rosa (2016), Nunes (2017), Quiroga (2005), Vargas (2005) e Rodrigues (2005).

Os sentidos da prática religiosa na prisão são abordados por Quiroga (2005). Não obstante a lógica fundamentalista e opressiva que marca a prática religiosa na prisão, náo se pode olvidar que a religiáo representa uma oportunidade de singularização dos sujeitos, sendo que, para a autora, esta singularização é um processo que opera nas seguintes dimensões: (i) no acolhimento do sujeito desviante e sua família; (ii) na elaboração de uma justificação místico-religiosa de sua culpabilidade; (iii) na construção de uma espécie de universo de "irmãos" em um contex $\neg$ to que se mostra ameaçador.

Vilhena (2015) percebe as religiosidades no cárcere a partir das possibilidades de emergência de um discurso norteador de condutas. As noçóes de "proceder" e "conversão religiosa" são centrais nessa discussão. De modo mais preciso, esse "proceder" se refere a um complexo número de regras criadas pelos detentos e seguidas ou não pelos presos. Já a ideia de "conversáo religiosa" é utilizada no sentido de visibilizar a mudança de visão de mundo do sujeito que cumpre pena de prisão. O que a autora defende, então, é que, a partir da conversão, o sujeito desviante passaria por uma reforma moral subjetiva refletida nas relaçóes com o coletivo e, assim, adotaria os preceitos e valores cristãos em forma de uma conduta moralmente aceitável, o que implica um "proceder religioso" na prisão.

Rodrigues (2005), por seu turno, afirma que a conversão ou adesão religiosa assenta-se em um mecanismo que possibilita uma espécie de reorganizaçáo das biografias dentro da prisão, "[...] a religião encarada como um sistema cultural, uma 'rede de significados', possibilita interpretaçôes e modificaçóes resultantes de um processo comunicacional característico do jogo interacional entre atores sociais negociando a realidade" (Rodrigues, 2005, p. 11).

No estudo realizado por Livramento Rosa (2016), identifica-se que a religiosidade é uma via possível para lidar com o encarceramento ao permitir que os sujeitos que cumprem pena signifiquem as suas vidas, seja no âmbito da prisão ou mesmo fora dela. "Por meio do encontro com o mundo religioso, os internos parecem sentir certa autonomia em suas vidas" (Livramento; Rosa, 2016, pp. 423-424). Todavia, a vivência religiosa parece limitar o sujeito quanto a uma compreensão mais crítica das suas condiçôes de vida, reforçando, por sua vez, o discurso da culpabilização do sujeito. "Questóes políticas, econômicas e sociais que atravessam a criminalidade são desconsideradas, ou minimizadas, em detrimento de explicaçóes transcendentais e naturalizadas", ressalta Livramento e Rosa (2016, p. 424).

Com o objetivo de analisar o efeito do discurso religioso na ressignificaçáo do eu de homens que cumprem pena no presídio de Cataguases (cidade do Estado de Minas 
Gerais) e avaliar o impacto dessa ressignificação sobre o comportamento destes homens dentro e fora das celas, Nunes (2017) identifica quatro formas básicas de ressignificação do eu pelo discurso religioso que alteram a percepção que esses homens têm de si mesmos, dos outros e, consequentemente, do mundo. Na primeira possibilidade de ressignificação, sob a denominação de "ressignificação temporária", o sujeito ressignifica o seu eu temporariamente, diante das circunstâncias em que vive na prisão. Ou seja, a adesão ao discurso religioso se relaciona a alguns propósitos bem específicos, quais sejam, alcance de proteção no espaço social da prisão ou mesmo ganhar a confiança do juiz ou equipe dirigente a fim de conseguir sua liberdade. Na segunda possibilidade, que se chama de "ressignificação profunda", o discurso religioso leva o sujeito desviante a fazer uma revisão de sua trajetória de vida e, consequentemente, se arrepender dos atos cometidos. O discurso religioso, atrelado a uma ideia de mudança, passa a ser usado para explicar fatos da vida do sujeito, a pena e a vida da prisáo. O que acontece na chamada "ressignificação polissêmica" é que o sujeito se apropria do discurso religioso, inserindo o mesmo em um contexto de polissemia. Especificamente, o sujeito se apropria do discurso religioso adequando semelhante discurso aos modos de viver no crime, na medida em que, o sujeito, em suas oraçóes, pede a proteção em uma fuga ou mesmo assistência no planejamento de um homicídio. Por fim, a quarta possibilidade de ressignificação do eu a partir do discurso religioso, "ressignificação crítica", identifica as posições de sujeitos que se mostram contrários à religião. Assim, o sujeito que cometeu crimes se apropria do discurso religioso a fim de questioná-lo (Nunes, 2017).

Nos espaços sociais da prisão, a religiáo é então incluída no conjunto dos chamados mecanismos de "adaptação-resistência", os quais, para Vargas (2005, p. 26) "[...] são espaços intermediários e brechas do sistema prisional, onde a vida e a singularidade pedem passagem subordinada e limitada ao poder e controle e, ao mesmo tempo, em coexistência negociada com eles". Esses mecanismos estáo calcados em um conceito de híbrido, pois se referem aos discursos e comportamentos adaptativos como formas de resistência (Vargas, 2005).

Considerando alguns aspectos da analítica foucaultiana (Foucault, 1988; 2008), a linha de argumentação neste artigo estabelece que a produção de subjetividades por meio de práticas discursivas religiosas é um processo em que estão implicadas dinâmicas de poder, que remetem a uma noção de poder pastoral, bem como a uma ideia de bipoder.

O exercício das práticas religiosas nas prisóes se refere, em um nível, a uma tecnologia do poder pastoral. O poder pastoral, que se desenvolveu desde os séculos II e III até o século XVIII, associa-se ao processo de formação das sociedades cristâs; no entanto, Foucault (2008, p. 197) ressalta que o poder pastoral "[...] por certo foi deslocado, desmembrado, transformado, integrado a formas diversas, mas no fundo nunca foi verdadeiramente abolido".

O poder pastoral se caracteriza pelas relaçóes de poder existente entre o pastor e seu rebanho e, neste sentido, insere no mundo ocidental, para além de um governo das coisas, o pressuposto de um governo dos vivos, ou mais precisamente, das almas. Delineia-se, assim, da arte de conduzir, que Foucault (2008, p. 2018) explica:

O pastorado, no cristianismo, deu lugar a toda uma arte de conduzir, de dirigir, de levar, de guiar, de controlar, de manipular os homens, uma arte de segui-los e de 
empurrá-los passo a passo, uma arte que tem a função de encarregar-se dos homens coletiva e individualmente ao longo de toda a vida deles e ao passo de sua existência.

Foucault (2008) relaciona o poder pastoral ao dispositivo da confissão, dispositivo este que se origina da vontade de saber, de conhecer a verdade dos indivíduos e de (re) formar este saber. Destarte, por meio deste exame de consciência, o pastor é aquele que sabe a respeito do seu rebanho e, principalmente, é aquele que sabe o que é preciso para a salvação de cada uma das "ovelhas" de seu rebanho, sendo esta lógica salvacionista um dos aspectos característicos do poder pastoral:

\begin{abstract}
O pastorado está relacionado com a salvação, pois tem por objetivo essencial, fundamental, conduzir os indivíduos, ou, em todo caso, permitir que os indivíduos avancem e progridam no caminho da salvação. Verdade para os indivíduos, verdade também para a comunidade. Portanto ele guia os indivíduos e a comunidade pela vereda da salvação. Em segundo lugar, o pastorado está relacionado com a lei, já que, precisamente para que os indivíduos e as comunidades possam alcançar sua salvaçấo, deve zelar por que eles se submetam efetivamente ao que é ordem, mandamento, vontade de Deus. Enfim, em terceiro lugar, o pastorado está relacionado com a verdade, já que no cristianismo, como em todas as religióes de escritura, só se pode alcançar a salvação, e submeter-se à lei com a condição de aceitar, de crer, de professar certa verdade. Relação com a salvação, relação com a lei, relação com a verdade. O pastor guia para a salvaçáo, prescreve a Lei e ensina a verdade (Foucault, 2008, p. 221).
\end{abstract}

Além disso, em outro nível, as relações entre religião e prisão podem ser interpretadas a partir da noçáo do chamado biopoder, o que se pode associar a um poder sobre a vida. Sobre a biopolítica, Foucault $(2008$, p. 89) diz que é "[...] a maneira pela qual se tentou, desde o século XVIII, racionalizar os problemas propostos à prática governamental, pelos fenômenos próprios a um conjunto de seres vivos constituídos em população: saúde, higiene, natalidades, raças [...]". De um modo, o que perpassa a biopolítica são os processos de identificação e a definição dos parâmetros que norteiam a vida da população, o que viabiliza o controle das anomalias que acometem os corpos e vidas (mazelas sociais, epidemias, endemias, etc.).

Compreende-se que um dos efeitos desse biopoder no contexto das prisóes está relacionado ao processo de inserção do chamado discurso religioso nestes espaços sociais. Em linhas gerais, ressalta-se que o exercício da prática religiosa é algo que aparece no dito aparato legal. De acordo com a Lei de Execução Penal, No 7210/1984:

Art. 24. A assistência religiosa, com liberdade de culto, será prestada aos presos e aos internados, permitindo-se-lhes a participação nos serviços organizados no estabelecimento penal, bem como a posse de livros de instruçáo religiosa.

$\$ 1$. No estabelecimento haverá local apropriado para os cultos religiosos.

$\$ 2^{\circ}$. Nenhum preso ou internado poderá ser obrigado a participar de atividade religiosa.

O Estado, ao instituir a garantia da assistência religiosa nos espaços de cumprimento de pena de prisão, insere a prática religiosa como mecanismo de normalização de condutas de sujeitos desviantes, um dispositivo que atua no processo de ressocializaçáo dos sujeitos que cometeram crimes. A religião é estratégia biopolítica para controle e docilização das vidas da população carcerária.

Náo se pode ignorar que as prisóes se inserem na categoria que Goffman (1961) nomeia de instituições totais, espaços constituídos por um conjunto de processos, práticas 
e procedimentos que se baseia na violência da autonomia do ato, ou no que autor chama de processos de mortificação do eu. É preciso apontar que não se faz a discussão acerca do poder e seus efeitos na prisão para reforçar esta representaçáo totalizante da prisão. Ao adotar uma perspectiva de que o poder é relacional, positivo e produtivo, ao invés de calcar puramente em um aspecto de repressão e/ou negativo (Foucault, 1988), chama-se a atenção para a possibilidade de resistências. Onde há poder há resistência, lembra Foucault (1988). Desse modo, no presente texto, o entendimento da prisão é como espaço social de lutas em que as condiçôes de vida são impostas e, ao mesmo tempo, negociadas e transformadas; como um espaço social em que a submissão e a ruptura são dois momentos ou duas açôes de um mesmo sujeito reflexivo; e, ainda, como um espaço social de convivência entre o homogêneo (com ares de totalizante) e o plural, como um espaço em que os discursos, dentre os quais o discurso religioso, produzem subjetividades normalizadas ou não.

\section{Metodologia}

Com o objetivo de analisar as relaçôes entre discurso religioso e produção de subjetividades em uma prisáo feminina, realizou-se uma pesquisa que se caracteriza por uma abordagem qualitativa, a qual, segundo Godoy (1995), valoriza a análise acurada do ambiente natural de determinado fenômeno, ou seja, o contato com o espaço em que ocorre e do qual é parte, sendo a perspectiva dos sujeitos participantes do estudo elemento primordial na compreensáo de tal contexto.

Compartilhamos do pressuposto de que uma determinada pesquisa encerra caráter qualitativo ou quantitativo devido à natureza do problema, bem como dos objetivos que orientam a investigaçáo (Godoy, 1995), e neste estudo, a abordagem qualitativa se justifica pelo fato de que a compreensão das dinâmicas que norteiam as relaçóes entre discurso religioso e produção de subjetividades requer uma análise profunda das percepçôes dos sujeitos envolvidos nestas relaçóes.

O método escolhido foi o estudo de caso, uma estratégia que se baseia na investigaçáo profunda de fenômenos contemporâneos que fazem parte de determinado contexto social, principalmente quando se apresentam pouco discerníveis os limites entre fenômeno e contexto. Especificamente, trata-se de um estudo de caso descritivo que intenta a análise do objeto de estudo a partir da descrição dos aspectos e associações que lhe conformam, isso tendo em vista uma teoria previamente definida. Interessa descrever os sentidos produzidos acerca das práticas religiosas no cotidiano da prisão.

Empreendeu-se o presente estudo de caso na unidade feminina de um dos centros de ressocialização da Associação de Proteção aos Condenados (APAC), unidade esta que se localiza em uma cidade do interior do Estado de Minas Gerais. Na época da pesquisa, o centro de ressocializaçáo abrigava cerca de 30 mulheres recuperandas que cumpriam sentenças nos regimes fechado, semiaberto e aberto, conforme prevê a Lei de Execução Penal.

Conforme já dito, a produção de sentidos subjetivos sustenta a problemática desta pesquisa (González Rey, 2003; 2009). Assim, o principal instrumento de elucidação 
destes sentidos subjetivos foi a entrevista semiestruturada. Foram realizadas 26 entrevistas com as recuperandas e quatro entrevistas com os membros do que chamamos de equipe dirigente. Cada entrevista durou, em média, 50 minutos, tendo todas elas sido gravadas e, posteriormente, transcritas. Este artigo é parte de uma pesquisa mais abrangente que tinha o objetivo de analisar as relaçóes entre as categorias de cultura, lugar e subjetividades em uma prisão feminina. A proximidade que a pesquisadora ${ }^{1}$, uma das pessoas que escrevem este texto, obteve no campo de pesquisa com os sujeitos e sujeitas, permitiu uma abordagem profunda de temas complexos como o papel da religiáo naquele espaço da prisão, bem como a relaçáo individual que as recuperandas tinham com a religião.

É preciso, nesta pesquisa, considerar a influência das subjetividades da pesquisadora que realizou as entrevistas e que as analisou. Ser mulher cis, heterossexual, branca, de classe média, estudante de pós-graduação em uma universidade pública e que mora na capital do Estado de Minas Gerais demarcou os encontros e desencontros com as mulheres na prisão. $\mathrm{O}$ fato de ser estudante e morar na capital me aproximou de muitas mulheres que desejavam saber como era morar em Belo Horizonte e/ou estudar na Universidade Federal de Minas Gerais (UFMG). Mas, compreendo que, por outro lado, tais marcadores me distanciaram de outras mulheres que ficavam desconfiadas de eu estar indagando sobre suas vivências ou mesmo ficavam envergonhadas por pensar que não conseguiriam conversar comigo direito.

A investigação presente está sustentada, ainda, na premissa de que, por meio das práticas discursivas, compreender-se-á a produção de sentidos que se desenvolve na dinâmica das relaçôes sociais historicamente constituídas e culturalmente localizadas (Spink; Medrado, 1999). Deste modo, as entrevistas transcritas constituíram um corpus que foi interpretado tendo em vista o uso da técnica de análise do discurso em sua vertente francesa (Maingueneau, 1998). Os trechos em itálico são destacados pelos autores por se tratar de fragmentos discursivos que serão analiticamente trabalhados.

\section{Apresentaçáo e discussáo dos resultados}

Nesta seção, apresentam-se os discursos que foram produzidos a partir dos processos dialógicos estabelecidos com os sujeitos da pesquisa. De modo geral, tais processos dialógicos versaram sobre o exercício das práticas religiosas na APAC, como tais práticas são inseridas no cotidiano da prisão e delimitam as trajetórias subjetivas e relaçóes sociais na prisão. A primeira parte é composta pela análise dos discursos de membros que pertence à chamada equipe dirigente da APAC. Logo em seguida, estáo organizados os discursos das mulheres que cumprem pena de prisão naquele espaço social.

1 Este artigo foi escrito a quatro mãos, mas o trabalho de campo foi realizado pela primeira autora. Neste sentido, quando, neste texto, for feito o uso de verbos conjugados na primeira pessoa, a referência recai sobre as experiências desta autora no campo. 
Discurso religioso e produção de subjetividades em uma prisão feminina...

\section{"A APAC é um local de Deus, aqui não prega religiāoo": um paradoxo entre a autonomia e o controle}

Inicia-se esta parte da análise com um trecho do livro "Vamos Matar o Criminoso? Método APAC", trecho que, de certa forma, ajuda a situar o "lugar" da religião, um dos doze elementos do Método $\mathrm{APAC}^{3}$, no espaço social da APAC. O método representa o conjunto de políticas, práticas e processos relacionados ao objetivo de recuperação dos sujeitos que cometeram crimes. O chamado Método APAC possui doze elementos, a saber: (i) participaçáo da comunidade; (ii) recuperando ajudando recuperando; (iii) trabalho; (iv) religião; (v) assistência jurídica; (vi) assistência à saúde; (vii) valorização humana; (viii) família; (ix) o voluntário e sua formação; (x) centro de reintegração social (CSC); (xi) mérito; e (xii) a jornada da libertação com Cristo.
A religião é fator primordial; a existência de Deus, de amar e ser amado, é de uma importância incomensurável, desde que pautada pela ética e dentro de um conjunto de propostas em que a reciclagem dos próprios valores leve o recuperando a concluir que Deus é o grande companheiro, o amigo que não falha. Essa experiência de vida deve nascer espontaneamente no coração do recuperando para que seja permanente e duradoura (Ottoboni, 2001, p. 78).

Geraldo ${ }^{4}$, um dos membros da equipe dirigente, fala do papel da religiáo na APAC e reproduz essa ideia de "importância incomensurável” da religiáo, conforme apontado no trecho atribuído a Ottoboni (2001).

(001) A APAC é um local de Deus, aqui não prega religião. O pessoal vem, tem um trabalho ecumênico para todo mundo, e tem um momento que é só para os católicos e o momento que é só para os evangélicos. Ninguém tem que puxar sardinha para ninguém. Não existe proselitismo e, quando existe, a gente corta. Ensinamos isto nos cursos de voluntários, ensinamos isto para os padres, para os pastores. Por exemplo: "Quando vocês forem visitar a cuidado com as palavras de vocês, não vêm pregar placa de religião, não. Você tem que pregar sobre Jesus'. Quando ele ou ela sair daqui eles váo ter a liberdade de procurar, de acordo com a família, de acordo com a crença deles. Mas, eles vão ter a liberdade de procurar. E os recuperandos têm que definir, você quer ir no evangélico, no católico, ou em qual. Tem que ter uma base religiosa aqui. Ahh, se alguém pergunta assim: 'Ah, mas se chegar um ateu na APAC?!'. D. Mário Ottoboni, em 40 anos, nunca viu isso. Porque o preso, por sua própria psicologia, ele só pensa em ganhar vantagem em alguma coisa. Olha, ele já está preso, ele pode ter ateu, ele quando chega na APAC a primeira coisa que ele procura saber é o quêe!! 'O presidente da APAC éo quê??! Católico. Ah, então eu também sou católico. Ah, o presidente é evangélico, então, eu também sou evangélico'. Já foi provado isto. Dificilmente, eu acho que nunca aconteceu, de chegar alguém que diz que não acredita em Deus. Eles não falam que Deus não existe não. Eles podem não ter uma afinidade com Deus, mas eles não falam que ele não existe não. É muito difícil alguém dizer que é ateu. Mas, às vezes, no mundo de hoje com as coisas com maior liberdade né, não sei. Mas, se for o caso de alguém falar, a gente vai fazer um trabalho com ele. Ele pode ficar 10 anos ali e quando ele sair náo vai para

\footnotetext{
2 Trata-se de um dos trechos dos discursos.

3 O método representa o conjunto de políticas, práticas e processos relacionados ao objetivo de recuperação dos sujeitos que cometeram crimes. O chamado Método APAC possui doze elementos, a saber: (i) participação da comunidade; (ii) recuperando ajudando recuperando; (iii) trabalho; (iv) religião; (v) assistência jurídica; (vi) assistência à saúde; (vii) valorização humana; (viii) família; (ix) o voluntário e sua formação; (x) centro de reintegração social (CSC); (xi) mérito; e (xii) a jornada da libertação com Cristo.
}

4 Neste texto, quando utilizamos trechos de falas das entrevistadas e dos entrevistados, optamos pela nomeação fictícia dos mesmos. 
igreja nenhuma. Agora, eu estou livre e não vou a lugar nenhum porque não acredito em Deus, por exemplo. E aqueles 10 anos que ele ficou ali, ele agradou a todo o mundo mas, dificilmente ele vai brigar. Muitos pensam: 'Eu não vou falar que eu sou ateu porque senão eles não vão deixar eu ficar aqui'. Então, para agradar os outros, ele acaba falando. Eu creio que em algum momento pode ter chegado algum. Mas, neste momento, com tanto trabalho que tem na APAC, jornada e tal, todos eles acabam acreditando em Deus. Às vezes, até depois não procura alguma igreja, mas ele acabou acreditando em Deus, nesta força, neste Deus que existe, neste ser que realmente perdoa, que gera este mundo. E aí você faz a pessoa pensar num monte de coisas (Geraldo, entrevista pessoal, 2013).

Mais precisamente, Geraldo, em seu discurso, explicita a obrigatoriedade de, no âmbito da APAC, o sujeito possuir um conjunto de crenças religiosas. A esse respeito, a seleçáo lexical a seguir é elucidativa: "E os recuperandos tem que definir, você quer ir no evangélico, no católico, ou em qual. Tem que ter uma base religiosa aqui”. O fragmento se constitui, assim, pelo discurso do controle. As relaçōes que o sujeito estabelece com alguma crença religiosa (ou melhor dizendo, com algo associado ao que é espiritual) são objeto de regulação no espaço social da APAC. Ao sujeito não é conferida autonomia sobre a decisão de crer ou não. Essa autonomia é cogitada apenas nos espaços socais para além dos muros da prisão. $\mathrm{Na}$ sociedade mais ampla, o sujeito pode ter essa liberdade de escolha mas, na APAC, pressupóe-se que o mesmo se encontra preso à necessidade de crer em algo. A seleção lexical que permite tal interpretação é a seguinte: "Quando ele ou ela sair daqui, eles vão ter a liberdade de procurar, de acordo com a família, de acordo com a crença deles. Mas, eles vão ter a liberdade de procurar”.

É importante dizer que Geraldo já foi um recuperando da APAC masculina naquela mesma cidade e em nossas conversas, ao longo do nosso contato, sempre ressaltava a importância do "pilar da religião" em sua recuperação. E dizia que resolveu aceitar a missão de salvar outras pessoas do mundo do crime. $\mathrm{Na}$ época das entrevistas, Geraldo ocupava uma posiçáo identificada como coordenador do método em ambas as unidades da APAC, feminina e masculina.

Os fragmentos do discurso de Geraldo nos fazem refletir que, não obstante a afirmação de que a APAC não obriga a adoção de uma religião específica, as possibilidades de escolha se concentram nas religióes de base cristá, quais sejam, a católica e evangélica. Já para os que não manifestarem disposição em acreditar em algum princípio religioso (ou espiritual), existe a possibilidade da catequização, a qual, segundo quem enuncia, na maioria das vezes, percebe resultados positivos. Delimitando a ideia do doutrinamento aponta-se a seleção lexical: "É muito difícil alguém dizer que é ateu. Mas, às vezes, no mundo de hoje com as coisas com maior liberdade né, não sei. Mas, se for o caso de alguém falar, a gente vai fazer um trabalho com ele". E, por fim, os possíveis resultados desse doutrinamento, são inferidos de: "Mas, neste momento, com tanto trabalho que tem na APAC, jornada e tal, todos eles acabam acreditando em Deus".

Neste fragmento discursivo (001), um dos aspectos refratados refere-se à generalizaçáo que se faz do modo como o sujeito, que vive em um estabelecimento prisional, se relaciona com um dado sistema de crenças religiosas. Para Geraldo, a tendência é de que os sujeitos se alinhem às crenças religiosas dos membros responsáveis pela gestão da organizaçáo em que aqueles primeiros cumprem sua pena privativa de liberdade. Precisamente, esse fenômeno da refração linguística está encerrado no trecho a seguir: 
"Porque o preso, por sua própria psicologia, ele só pensa em ganhar vantagem em alguma coisa. Olha, ele já está preso, ele pode ter ateu, ele quando chega na APAC a primeira coisa que ele procura saber é o quê?! ' $O$ presidente da APAC é o quê?! Católico. Ah, então eu também sou católico. Ah, o presidente é evangélico, então, eu também sou evangélico. Já foi provado isto". Esta seleçâo lexical alude ao que Nunes (2017) nomeia de "ressignificação temporária", isto é, a adoção de um discurso religioso seria para alcançar privilégios na prisão.

A noção da religião como mecanismo de controle na prisão aparece de modo específico na seleção lexical: "Ele pode ficar 10 anos ali e quando ele sair não vai para igreja nenhuma. Agora, eu estou livre e não vou a lugar nenhum porque não acredito em Deus, por exemplo. E aqueles 10 anos que ele ficou ali, ele agradou a todo o mundo mas, dificilmente ele vai brigar". O implícito pressuposto é que a religiáo é um meio de controle dos comportamentos de quem cumpre pena. A religiáo, desse modo, arrefece os conflitos. Por esta ótica, o exercício de uma prática religiosa promove a docilização dos comportamentos (e das almas) dos sujeitos desviantes. Baseando-se em Foucault (2008), a religião é mecanismo de um poder pastoral que se faz referência a um processo de condução das almas.

O fragmento (002), que contempla o discurso de Glória, gerente do centro de ressocialização à época, enuncia o papel da religiáo no processo de ressocialização.

(002) O que a gente tenta fazer com essa recuperanda enquanto ela está aqui dentro?! Por exemplo, a APAC não prega placa de igreja. Mas, ela tenta, através do nosso trabalho de religiäo e espiritualidade, a gente tenta mostrar pra essa recuperanda, por exemplo, a experiência com Deus. Mas, não só a experiência com Deus, sim o amor que Deus tem por nós, porque isso é viver em sociedade. Então a APAC vê hoje, aqui temos a igreja católica, a igreja evangélica. Se essa recuperanda, a partir do momento que ele está aqui dentro da APAC, se ela consegue se decidir, por exemplo, "ah, quero realmente ser católica”, aí ela participa das missas, ela vai ser batizada, ela vai fazer primeira eucaristia e tal. Quando essa recuperanda sair daqui, na verdade, ela já vai inserido na sociedade, porque ela vai continuar indo à missa com aquele padre que aqui frequentava, se for evangélica, com aquele pastor que aqui frequentava. Na verdade, isso já é porta, isso falando da religiáo (Glória, entrevista pessoal, 2013).

Em um discurso que se constitui pelos temas da religiáo, espiritualidade, doutrinamento (ou catequese) e da mudança (sendo estes dois últimos temas implícitos), Glória discorre sobre como a experiência de adesão religiosa na prisão se constitui como etapa importante para a reinserção na sociedade dos sujeitos desviantes. Vistos os elementos de uma analítica foucaultiana do poder (Foucault, 1988; 2008), o que sustenta esse discurso é uma concepção de que a religião é estratégia biopolítica, precisamente, um instrumento que permite normalizar a população de sujeitos criminosos. A ideia de controle sobre o sujeito em relação às experiências que vive na prisão, principalmente, em relação ao espiritual, pode ser interpretada a partir da seleção lexical: "o que a gente tenta fazer com essa recuperanda enquanto ela está aqui dentro?! Por exemplo, a APAC não prega placa de igreja. Mas, ela tenta, através do nosso trabalho de religiáo e espiritualidade, a gente tenta mostrar pra essa recuperanda, por exemplo, a experiência com Deus". O discurso é o da ressocialização dos sujeitos que cometeram crimes. Um aspecto ideológico defendido e que tem relaçáo com os efeitos do biopoder (Foucault, 1998), nesse âmbito, é de que a prática de uma religião está relacionada com a vida (normal) 
em sociedade. A seleção lexical que permite essa interpretação específica é: "Mas, não só a experiência com Deus, sim o amor que Deus tem por nós, porque isso é viver em sociedade". Pressupóe-se que a prática da religião na APAC influencia a mudança do sujeito que cometeu crime, conforme a seleçáo lexical: "Quando essa recuperanda sair daqui, na verdade, ela já vai inserida na sociedade, porque ela vai continuar indo à missa com aquele padre que aqui frequentava, se for evangélica, com aquele pastor que aqui frequentava”. A premissa da ressocialização por meio da religiáo se aproxima, por outro lado, do ideário da salvaçáo, característica do poder pastoral (Foucault, 2008).

\section{Permanecendo (ou não) na APAC: a "escolha" da religião}

As mulheres que cumprem pena produzem sentidos acerca das experiências que vivem em relação à religião na APAC. Nos fragmentos discursivos (003) e (004), as recuperandas evidenciam a questão da adesão religiosa como uma prática social na APAC.

(003) Eu sou católica. Aqui, quem é católica pratica a religiáo católica, quem é evangélica pratica a religiâo evangélica, né. Quando a gente chega aqui já pergunta: 'Você é católica, evangélica, espírita' [Mas a pessoa pode não ter uma religião?] Ateu? [Sim.] Não. Não tem como a pessoa ser ateu aqui, não. Ela tem que acreditar em Deus ou qualquer outra coisa, né. [Mas e se, por acaso, chegar uma pessoa aqui que não tem religião?] Uai, se acontecer isso, acho que vai arrumar uma religiäo pra ela, você quer ser o que, católica, espirita, crente?! Náo existe a pessoa estar sem religião, não. Porque tipo assim, eu chego aqui, não tenho nenhum tipo de religiáo, que Deus que eu sigo?! Tem que seguir a Deus né, seja na católica, no espiritismo ou na evangélica. Isso é muito importante, até por causa do Método também, né. Existe a religiäo naquelas regras lá do Método. Isso é muito importante (Júlia, entrevista pessoal, 2013).

(004) [A pessoa pode não ter religião?] Uai, se você não for batizado, se você não for batizado, se for pagão, aqui você pode encontrar a sua religiäo, pode conseguir o seu batismo. Porque tem voluntários católicos, padres, pastores. A gente tem missa. A gente tem a missa, tem os cultos evangélicos, tem o estudo bíblico. Então se você quiser até batizar, você pode batizar. Mas aí vai depender da pessoa, qual a religião que ela vai querer, vai escolher. O importante na APAC é ter uma religiẫo (Ana, entrevista pessoal, 2013).

Júlia e Ana sugerem a obrigatoriedade da adesão a alguma crença religiosa por parte dos sujeitos que cumprem pena na APAC. Não se concebe a possibilidade do náo crer em algo, como está exposto na seleçáo lexical do trecho discursivo (003): "Não tem como a pessoa ser ateu aqui, não. Ela tem que acreditar em Deus ou qualquer outra coisa, né". O sujeito precisa se inserir (ou ser inserido) em alguma "categoria" que tange ao religioso (ao espiritual), isto é, o processo de escolha concerne a qual "categoria religiosa” o sujeito quer pertencer. Essa inferência baseia-se no que diz Júlia, recuperanda que está há quatro meses cumprindo pena de prisão no regime fechado da APAC: "Uai, se acontecer isso, acho que vai arrumar uma religiáo pra ela, você quer ser o que, católica, espírita, crente?!". Ana, uma mulher branca que antes da prisão por tráfico de drogas era prostituta, conta em nossas interaçóes ao longo da pesquisa que em momento anterior ao ingresso na APAC cumpriu pena em outras cadeias e presídios do dito "sistema comum". Nesse tempo, agrediu e foi agredida, e ressalta as condiçóes precárias às quais era submetida em tais lugares. Neste trecho (004), Ana defende a obrigatoriedade da "escolha" religiosa na APAC. A seleção lexical que permite fazer 
aquela interpretação é: "Uai, se você não for batizado, se você não for batizado, se for pagão, aqui você pode encontrar a sua religião, pode conseguir o seu batismo. Porque tem voluntários católicos, padres, pastores”.

Regulamenta-se, assim, a disposição do sujeito em definir suas crenças, sendo tal regulamentação concretizada na figura discursiva do "Método", conjunto de princípios relativos ao trabalho que se pretende realizar na APAC. A partir do tema implícito da disciplina, depreende-se, por assim dizer, que a adesão religiosa incorpora um sentido de adesão do sujeito às regras APAC. Pela seleção lexical “Tem que seguir a Deus né, seja na católica, no espiritismo ou na evangélica. Isso é muito importante, até por causa do método também, né. Existe a religião naquelas regras lá do Método", Júlia demonstra, pois, consciência da "necessidade" de crer em algo, haja vista o arcabouço normativo da APAC. Exercer uma prática religiosa é uma questão de sobrevivência na APAC, e entende-se que tal, além de referir ao controle, incorpora também um sentido de singularização de quem enuncia (Quiroga, 2005).

Já nos enunciados (005) e (006), Maria e Deolinda falam a respeito de suas experiências no que tange à conversão religiosa.

(005) Quando eu vim pra cá, eu era católica. Mas, não praticante. E aí, aqui, foi trabalhado, aonde teve o dia da valorização humana e tudo e aonde entra religião como um dos doze elementos do Método da APAC e foi aonde eu fui me achar. E, hoje, para ser honesta com você, eu participo dos cultos e então hoje eu sou capaz de ter aquela visão da religião, a forma de acreditar em Deus é completamente diferente. Hoje, eu posso te falar que eu me sinto bem com os cultos evangélicos. Um trabalho mais assim, onde fala de Jesus mesmo. Hoje, não adoro imagem. Eu era católica, mas não praticante. Porque na minha casa era todo mundo católico e então tinha aquele negócio de imagem e tudo, e aqui eu fui conhecer a palavra. Não foi ninguém que me contou. Eu fui conhecendo, descobrindo, e aí eu pude tomar a decisáo do que é que eu queria. Quando você chega aqui, você responde um formulário do que você é e tal, qual religião você segue. Tem que ter uma religião né. Se você é espírita, aqui não tem um pessoal para te dar um apoio, mas a direção vai buscar. [...] Mas, você tem que ter uma religiáo. E aí você vai participando dos cultos, tem a missa, você pode praticar os dois, mas você tem que ter uma religião (Maria, entrevista pessoal, 2013).

(006) Eu sou evangélica. Aqui tem o culto. Na verdade, quando eu estava no presídio, nem religião eu tinha não. E ai eu comecei a participar dos cultos aqui na APAC e eu me interessei. Não é obrigado ir à missa não. Quem não quiser ir, não é obrigado, não. Eu vou porque não tem nada de mais, não, a gente conversa com Deus e tal, e é bom. $\mathrm{E}$, assim, na hora que a gente chega aqui na $\mathrm{APAC}$, na hora que eles vão conversar com a gente e tal, aí perguntam se é evangélica ou se é católica. Qual a religião que a gente tem, né, porque a gente tem que frequentar alguma coisa, né (Deolinda, entrevista pessoal, 2013).

Maria, mulher branca que está há 1 ano e 2 meses na APAC pelo crime de tráfico de drogas, estabelece um relato acerca da mudança de suas crenças religiosas, mudança esta que teria se processado quando da chegada daquela primeira no espaço social da APAC feminina. No referido fragmento discursivo, o fenômeno da conversão religiosa é sugerido quando da afirmação da enunciadora sobre sua participação em cerimônias ("cultos evangélicos"), bem como adoção de alguns princípios típicos ("Hoje não adoro imagem”) de uma religião distinta da que diz possuir antes de iniciar seu cumprimento de pena na APAC: "Quando eu vim pra cá, eu era católica". Converter-se a uma nova religião é um ato que influencia a percepção do sujeito sobre sua (re)adequação e 
bem estar no mundo. E4, quando diz "[...] foi aonde eu fui me achar [...]" ou "Hoje, eu posso te falar que eu me sinto bem com os cultos evangélicos", insere as crenças religiosas numa instância de promoção do autoconhecimento e do bem estar sujeito. Maria, que tem um filho de cinco anos fora dos muros da prisáo, em outros momentos em que interagimos, alinha seu discurso à noção de mudança ou transformação. Fala da mulher que foi, envolvida afetivamente com pessoas que a levaram para o mundo das drogas, e da mulher que tem se tornado hoje na APAC, muito em função de sua conversão religiosa, de seu "encontro com Jesus".

O discurso da conversão religiosa é construído a partir do percurso semântico da "escolha", mais precisamente, da escolha de qual religiáo seguir, pois o aspecto da obrigatoriedade parece permear essa relação do sujeito com a adoção de alguma crença religiosa: "Tem que ter uma religião, né". A figura discursiva do "formulário" demarca o início do que poder-se-ia chamar de processo de regulação da religião: "Quando você chega aqui, você responde um formulário do que você é e tal, qual religião você segue". O formulário materializa a prática da confissáo (Foucault, 2008) e permite a construçáo de um saber sobre os sujeitos.

No fragmento discursivo "Não foi ninguém que me contou. Eu fui conhecendo, descobrindo, e aí eu pude tomar a decisão do que é que eu queria", Maria busca delinear uma ideia de autonomia na escolha de um sistema de crenças religiosas (refraçáo linguística). No entanto, pela análise de outras construçōes frasais, depreende-se que o que é refletido linguisticamente é o controle (regulação) institucional sobre esse processo de escolha. Por exemplo, na seleção lexical "E aí, aqui, foi trabalhado, aonde teve o dia da valorização humana e tudo e aonde entra religião como um dos doze elementos do método da APAC e foi aonde eu fui me achar", a disposição para o ato de escolher um sistema de crenças religiosas parece despontar da participação do sujeito em atividades de cunho religioso.

A enunciadora do depoimento (006), Deolinda, também discorre sobre sua experiência de conversão religiosa ocorrida no espaço social da APAC. Assim sendo, a partir da relaçáo que estabelece (ou não) com os aspectos religiosos, o sujeito reflete sobre si mesmo, e suscita a questão da sua própria diferença em espaços sociais distintos, a APAC e o presídio, como se nota pela seleção lexical que segue: "Eu sou evangélica. Aqui tem o culto. Na verdade, quando eu estava no presídio nem religiáo eu tinha, não". A mulher negra de origem pobre, que está há 1 ano e um mês na APAC, em outro trecho que fala sobre sua vivência em outros espaços da prisão, ressalta: "Lá no sistema comum é horrível, eu era muito humilhada, muito difícil. Eu era muito revoltada. Depois que eu vim para cá é que a minha cabeça mudou. Porque minha cabeça, quando eu estava lá, não dava não, estava só piorando. Era só revolta que eu tinha. Não deixavam eu ligar para a minha mãe. E nem para os parentes. E aí eu pensava em sair e fazer coisa pior. Não pensava em mudar. Eles tratavam a gente muito mal. [...] Aqui na APAC eu já faço outros planos [...]".

Deolinda, ao usar o verbo "interessar", sugere autonomia quando da sua adesão a uma dada religiáo: "E aí eu comecei a participar dos cultos aqui na APAC e eu me interessei". O ato de interessar-se incorpora uma ideia de vontade, de disposiçáo do próprio sujeito. Todavia, o sentido de obrigatoriedade que perpassa essa decisão é 
explicitado no enunciado (006), mais especificamente, na seleção lexical: "Qual a religião que a gente tem né, porque a gente tem que frequentar alguma coisa né”. Deolinda, no fragmento discursivo "E, assim, na hora que a gente chega aqui na APAC, na hora que eles vão conversar com a gente e tal, aí perguntam se é evangélica ou se é católica”, deixa subtendido que o controle das crenças religiosas inicia-se quando do ingresso do sujeito na APAC.

As experiências de conversão religiosa das enunciadoras Maria e Deolinda evidenciam que os modos de estas mulheres se relacionarem com a prática religiosa na APAC (e enunciarem a respeito desta prática) são demarcados pelas vivências em outros espaços prisionais ou não. A produção de sentidos é, assim, histórica e contextualmente localizada, é algo que se relaciona à história do sujeito em determinado contexto social (e, ainda, em outros contextos sociais ao longo de sua trajetória) e, portanto, à maneira como os interesses e necessidades se organizam nesse determinado contexto social (González Rey, 2003; 2009).

Os trechos discursivos (007) e (008) são construídos a partir da reflexão que as recuperandas fazem sobre a importância da religião no contexto social da prisão.

(007) Sou evangélica. Temos a missa, e trabalho evangélico na APAC é sempre. Nos dias de segunda-feira tem o estudo bíblico, dia de quinta-feira tem o culto evangélico. E eu, como recuperanda, eu vou sempre na igreja, a gente pode ir na parte da manhã aos domingos. E não só aqui dentro, mas quando eu tenho saída, eu dou um tempo de ir na igreja. Eu dou um jeito de ir porque é uma coisa assim muito boa, é coisa que é palavra de Deus. Porque se não fosse Deus e minha familia, é difícil. E também principalmente a APAC também, uma coisa assim, é sem palavras, só Deus mesmo para ajudar. Como Deus me ajudou, ele vai ajudar muito ainda as recuperandas também. Pelo sofrimento mesmo, aqui. Aqui é difícil. [Você frequentava a igreja evangélica antes de você ser presa?] Não. Passei a frequentar a igreja evangélica aqui na Apac (Elza, entrevista pessoal, 2013).

(008) Religiāo aqui é obrigatória, porque cada um tem que ter uma crença. Não tem uma pessoa que não tem, muito difícil não ter. E aqui tem os cultos, os estudos bíblicos, a missa dia de quarta-feira. Aí quem é evangélico participa daquilo, quem é católico participa do outro. Só nâo tem de outra religião, porque aqui todo mundo ou é evangélico, ou é católico, entendeu?! E eu, sinceramente, acho que todo mundo tem que ter uma religiäo, uma crença, porque sem você acreditar em alguma coisa, pra mim, você não tem um propósito de vida. Porque a maior parte do tempo que você está aqui, você, porque aqui é muito difícil, eu acho que você tem que pegar mesmo na fé, na esperança, e isso tem muito na religiáo, entendeu?! (Conceição, entrevista pessoal, 2013).

O tema do sofrimento perpassa a justificativa que sustenta a adesão a alguma crença religiosa no período em que se cumpre na APAC. Nesse sentido, as dificuldades oriundas de um viver na prisão são minimizados mediante às experiências religiosas. Enuncia-se, portanto, o discurso da religiáo como mecanismo de refúgio para quem cumpre pena de prisão. Especificamente, Elza, mulher negra de 20 anos presa por tráfico de drogas e uma das poucas recuperandas que me confidenciaram o quão foi difícil o processo de adaptação ao conjunto de regras na APAC, aponta: "Porque se não fosse Deus e minha família, é difícil”. Em se tratando do fragmento (008), destaca-se a seleção lexical: "E eu, sinceramente, acho que todo mundo tem que ter uma religiáo, uma crença, porque sem você acreditar em alguma coisa, pra mim, você náo tem um propósito de vida. Porque a maior parte do tempo que você está aqui, você, porque aqui é muito difícil, eu 
acho que você tem que pegar mesmo na fé, na esperança, e isso tem muito na religiáo, entendeu?!" A religião é demarcada como prática necessária para os enfrentamentos a serem vivenciados pelas recuperandas. Em nossas conversas, Conceição, também uma mulher negra cumprindo pena por tráfico de drogas, diz que sua primeira prisão foi por estelionato e na prisão comum "conheceu pessoas" que a influenciaram a permanecer no mundo do crime. Na APAC, tem sido diferente, muito por conta de sua prática religiosa constante: "Porque a maior parte do tempo que você está aqui, você, porque aqui é muito difícil, eu acho que você tem que pegar mesmo na fé, na esperança, e isso tem muito na religiáo, entendeu?!”.

Para além da obrigatoriedade da adesão religiosa, os modos como se pratica determinada crença religiosa na APAC também são regulados pela referida organização.

(009) Eu sou evangélica. Aqui tem os cultos, sabe. E eu vou. Mas, antes eu orava para as pessoas como se fosse uma pastora, e aqui na APAC não pode este tipo de coisa. Se uma pessoa tivesse com dor de cabeça, por exemplo, eu orava pra ela naquela hora. Ai agora eu vou nos cultos, peço oração, participo dos cultos, sabe, isso pode. Mas aquilo que fazia, não faço mais (Pâmela, entrevista pessoal, 2013).

Mulher de 35 anos, nascida no Estado do Mato Grosso e uma das poucas recuperandas que diz ter o segundo grau completo, Pâmela enuncia o discurso do controle ao relatar uma situaçáo sobre o que se pode ou não realizar quando se trata de religião. Sob o tema implícito da interdição, a enunciadora evidencia que a prática da religiáo é inserida no espaço social da prisão tendo em vista uma estrutura de (im)possibilidades institucionais. Pâmela foi presa por envolvimento com o tráfico de drogas e está há quatro meses na APAC. Neste enunciado, a mulher fala sobre o que é proibido neste contexto: "Mas, antes eu orava para as pessoas como se fosse uma pastora, e aqui na APAC não pode este tipo de coisa". Além disso, Pâmela fala sobre o que é permitido: "Aí agora eu vou nos cultos, peço oração, participo dos cultos, sabe, isso pode. Mas aquilo que fazia, não faço mais".

\section{Consideraçóes finais}

Com o objetivo de analisar as relaçóes entre discurso religioso e produção de subjetividades em uma prisão feminina, realizou-se um estudo de caso na unidade feminina de um dos centros de ressocialização da Associação de Proteção aos Condenados (APAC). Partindo do pressuposto de que as interfaces entre o discurso religioso e a produçáo de subjetividades estão atravessadas por relaçóes de poder, seguiu-se uma linha de argumentaçáo que afirma que a produção de subjetividades por meio de práticas discursivas religiosas evidencia um processo em que estão implicadas as noçóes de pastoral e de biopoder (Foucault, 1988; 2008).

$\mathrm{Na}$ APAC, a prática religiosa, que se constitui como uma prática discursiva, se insere em um contexto de estratégia biopolítica na medida em que, em um primeiro nível, é garantida por uma razão governamental que permite, por meio do texto da lei, a assistência religiosa na prisão. Em outro nível, a ideia da prática religiosa como estratégia biopolítica se relaciona, e ao mesmo tempo, se confunde com os efeitos de um poder pastoral. 
A obrigatoriedade da prática religiosa, de início, caracteriza a religiáo como um dos mecanismos de controle usado a fim de manter calmas e dóceis as mulheres que cumprem pena. Pressupóe-se que a crença em algo para além das tensôes, dos conflitos de uma vida terrena, principalmente, de uma vida na prisão, atua de maneira a tranquilizar as recuperandas, diminuindo sua ansiedade. A religiáo, independentemente de qual seja, torna-se uma estratégia premeditada e calculada pelos membros da equipe dirigente da APAC a fim de despertar a paciência e a perseverança das recuperandas.

A ideia que subjaz esse uso da prática religiosa é a de condução das almas dessas mulheres, o que se relaciona com uma condução dos modos de ser e se relacionar no espaço da prisão, e por extensão, o que se pode denominar de produção de subjetividades normalizadas. Interpreta-se que a organização, a APAC, representa o papel como o pastor dessas almas, o pastor que tudo sabe a respeito de suas ovelhas. A ideia de ressocialização alude ao preceito de salvação, que faz parte do poder pastoral. No entanto, a ideia de "salvação" aqui se associa, na maioria das vezes, a uma "salvação" no âmbito da prisão, o que desloca o processo de ressocialização de uma dimensão individual (fazendo referência a uma mudança do sujeito) para uma dimensão do coletivo, precisamente, controle das relaçóes deste coletivo na prisão.

No entanto, considera-se simplista afirmar que, na APAC, a religiáo apresenta-se somente como estratégia de dominação, corroborando, pois, aquela perspectiva de dominantes, membros da equipe dirigente, e dominados, recuperandas. Nos espaços sociais da prisão, a prática religiosa pode ser incluída no conjunto dos chamados mecanismos de resistência. No caso da APAC, reconhece-se que a adoçáo de um sistema de crenças religiosas, não obstante os limites que resvalam da ideia de obrigatoriedade, não deixa de propiciar sentido e momentos de transcendência às recuperandas. Nesse caso, adotar um discurso religioso configura-se como uma tática de que as recuperandas se valem para solucionar conflitos decorrentes do viver na prisão. A resistência não se manifesta apenas nas oposições, mas também em modos que, em um primeiro momento, classificar-se-iam como submissos. Assim sendo, acredita-se na reflexividade do sujeito até mesmo na submissão. O exercício de uma prática religiosa, mais do que indica a posição de um sujeito obediente, um sujeito disciplinado, pode ser apenas uma estratégia usada para (sobre)viver em um espaço social em que pululam os interditos.

\section{Referências}

CRENSHAW, Kimberlé. Documento para o encontro de especialistas em aspectos da discriminação racial relativos ao gênero. Estudos Feministas, Florianópolis, v. 10, n. 1, pp. 171-188, 2002.

FOUCAULT, Michel. A arqueologia do saber. 7. ed. Rio de Janeiro: Forense Universitária, 2004.

FOUCAULT, Michel. História da sexualidade: a vontade de saber. 13. ed. Rio de Janeiro: Graal, 1988. 
FOUCAULT, Michel. Segurança, território, população: curso dado no Collège de France (1977-1978). Sáo Paulo: Martins Fontes, 2008.

GODOY, Arilda S. Introdução à pesquisa qualitativa e suas possibilidades. Revista de Administração de Empresas, São Paulo, v. 35, n. 2, pp. 57-63. mar./abr. 1995.

GOFFMAN, Erving. Manicômios, prisóes e conventos. Sáo Paulo: Perspectiva, 1961.

GONZÁLEZ REY, Fernando. Sujeito e subjetividade: uma aproximação históricocultural. São Paulo: Pioneira Thomson Learning, 2003.

GONZÁLEZ REY, Fernando. O social na psicologia e a psicologia social: a emergência do sujeito. 2. ed. Petrópolis: Vozes, 2009.

LIVRAMENTO, André M.; ROSA, Edinete M. Homens no cárcere: estratégias de vida na prisão. Pesquisas e Práticas Psicossociais, São João del-Rei, v. 11, n. 2, pp. 412-426, jul./dez. 2016.

MAINGUENEAU, Dominique. Termos-chave da análise do discurso. Belo Horizonte: UFMG, 1998.

MUMBY, Dennis K.; CLAIR, Robin P. Organizational discourse. In: VAN DIJK, T. A. (Ed.). Discourse as social interaction. London: Sage, 1997. pp. 181-205.

NUNES, Ana I. C. À porta das celas: a ressignificação do 'eu' através da influência do discurso religioso na prisão. Revista Eletrônica de Ciências Sociais, Juiz de Fora, n. 25, pp. 01-22, 2017.

ORLANDI, Eni P. A linguagem e seu funcionamento. 2. ed. Campinas: Pontes, 2003.

OTTOBONI, Mario. Vamos matar o criminoso? Método APAC. São Paulo: Paulinas, 2001.

PAULA, A. P. P.; PALASSI, M. P. Subjetividade e simbolismo nos estudos organizacionais: um enfoque histórico-cultural. In: CARRIERI, A. P.; SARAIVA, L. A. S. (Org.). Simbolismo organizacional no Brasil. São Paulo: Atlas, 2007.

QUIROGA, A. M. Religiōes e prisōes no Rio de Janeiro: presença e significados. Debates do NER, Porto Alegre, ano 6, n. 8, pp. 13-21, jul./dez. 2005.

RODRIGUES, G. E. Transgressão, controle social e religião: um estudo antropológico sobre práticas religiosas na penitenciária feminina do estado do Rio Grande do Sul. Debates do NER, Porto Alegre, ano 6, n. 8, pp. 09-20, jul./dez. 2005.

SPINK, M. J.; MEDRADO, B. Produção de sentidos no cotidiano: uma abordagem teórico-metodológica para análise das práticas discursivas. In: SPINK, M. J. (Org.). Práticas discursivas e produção de sentidos no cotidiano: aproximaçôes teóricas e metodológicas. São Paulo: Cortez, 1999. pp. 22-41. 
VARGAS, L. O. Religiosidade: poder e sobrevivência na penitenciária feminina do Distrito Federal. Debates do NER, Porto Alegre, ano 6, n. 8, pp. 21-37, jul./dez. 2005.

VILHENA, A.B. O "proceder religioso": uma breve análise sobre a conversão religiosa de detentos e sua relação com os demais atores religiosos na ordenação social da prisão. Anais do Congresso ANPTECRE, v. 5, 2015. Disponível em: $<\mathrm{http} / /$ www2.pucpr.br/reol/pb/index.php/5anptecre?dd1=15549\&dd99=view\&dd $98=\mathrm{pb}>$. Acesso em: $01^{\circ}$ de maio de 2018.

WESTWOOD, R.; LINSTEAD, S. Language/Organization: introduction. In: WESTWOOD, R.; LINSTEAD, S. (Ed.). The language of organization. London: Sage, 2001. pp. 01-19.

Recebido: 12 de março de 2019. Aprovado: 14 de janeiro de 2020. 